\title{
MEMBANGUN KARAKTER BANGSA MELALUI IMPLEMENTASI PENDIDIKAN KARAKTER ISLAMI DALAM KELUARGA
}

\author{
Alif Lukmanul Hakim \\ Universitas Islam Indonesia \\ Jl. Kaliurang KM 14,5 Yogyakarta \\ E-mail: alif.lukmanulhakim@uii.ac.id
}

DOI: 10.29313 /tjpi.v6i1.2580

Accepted: May 30th, 2017. Approved: July 20th, 2017. Published: July 20th, 2017

\begin{abstract}
This article describes the significance and urgency of the implementation of Islamic character education and its contribution in building the character of the nation. Especially when this nation is faced in an era of globalization that brings consequences. One of the negative consequences is the decline of moral values. Indonesian Muslim community can choose and sort the culture that is by Islamic teaching and national identity. Indonesian Muslims are expected to bave moral quality and integrity, so as to bring Indonesia to be a dignified and developed nation. In this context, the family as the first educational institution plays an important role in creating a good generation. Implementation of Islamic character education at the family level can be done by teaching children to Islamic behavior such as work ethic, honesty, and so on.
\end{abstract}

Keywords: National Character, Islamic, and Family.

\section{ABSTRAK}

Artikel ini memaparkan tentang signifikansi dan urgensi implementasi pendidikan karakter Islami serta kontribusinya dalam membangun karakter bangsa. Saat ini bangsa ini dibadapkan pada era globalisasi yang membawa konsekuensi. Salab satu konsekuensi negatifnya adalah melunturnya nilai-nilai moralitas. Masyarakat Muslim Indonesia dituntut dapat memilib dan memilab budaya yang sesuai dengan ajaran Islam dan jati diri bangsa. Muslim Indonesia diharapkan memiliki kualitas dan integritas moral yang kokoh, sehingga mampu membawa bangsa Indonesia menjadi bangsa yang maju dan bermartabat. Dalam konteks inilah, keluarga sebagai institusi pendidikan pertama memainkan peran penting dan sentral dalam melabirkan generasi bangsa yang berkarakter. Implementasi karakter pendidikan Islami di level keluarga dapat dilakukan dengan mengajarkan anak pada prilaku Islami seperti etos kerja, jujur, dan sebagainya.

Kata kunci: Karakter Bangsa, Islami, dan Keluarga. 


\section{PENDAHULUAN}

Keluarga merupakan institusi pendidikan pertama yang dilalui oleh seorang anak semenjak dilahirkan. Melalui keluarga, anak mendapat pengalaman belajar untuk pertama kalinya (first experience). Di institusi keluarga pula, intelektualitas dan moralitas anak terbentuk untuk pertama kalinya. Karena itu, orang-orang terdekat terutama orang tua - memiliki peran sentral dan signifikan dalam pembentukan moralitas dan intelektualitas anak. Dengan kata lain, masa depan anak terkait erat dengan model pendidikan yang diberikan oleh orang tua terhadap anak.

Sebagaimana diketahui bahwa apapun yang dilakukan oleh orang tua dengan serta merta akan dicontoh dan ditiru oleh anak. Karena itu tidak berlebihan jika keluarga disebut sebagai basis utama dalam pembentukan karakter seorang anak. Namun demikian, tidak banyak orang tua yang mengetahui dan menyadari peran penting mereka dalam membentuk karakter buah hati mereka. Buktinya, tidak sedikit orang tua yang melakukan tindak kekerasan, baik fisik maupun psikis ketika mendapati anaknya berbuat salah. Orang tua pada umumnya justru cenderung menyalahkan pihak lain ketika mengetahui anaknya nakal, bandel dan tidak mau menuruti aturan.

Selain itu, terdapat asumsi di kalangan orang tua yang mengatakan bahwa tugas dan tanggung jawab orang tua telah selesai ditunaikan manakala mereka telah mampu mencukupi kebutuhan material anak. Padahal kebutuhan seorang anak tidak hanya sebatas tercukupi secara material saja, namun kebutuhan yang bersifat immateri semisal perhatian, kasih sayang, dan keteladanan juga sangat penting. Maka, "wajar" jika ditemui fakta di lapangan banyak anak yang terlibat perkelahian, penyalahgunaan obat, seks bebas, dan tindakan-tindakan kriminal lainnya.

Tindakan-tindakan menyimpang yang dilakukan dan melibatkan anak-anak bisa jadi salah satunya dipicu oleh kurangnya perhatian dan kasih sayang orang tua terhadap anak. Anak akan berupaya mencari perhatian dengan melakukan hal-hal negatif diluar kontrol diri mereka. Jika realitas semacam ini yang yang terjadi, maka sungguh naif dan ironis kondisi bangsa ini di masa yang akan datang. Harapan untuk melahirkan generasi bangsa yang berkarakter hanya akan menjadi sebuah mimpi belaka.Padahal, anak-anak merupakan aset bangsa di masa depan yang kelak diharapkan dapat menjadi penerus untuk membawa bangsa Indonesia menjadi bangsa yang maju, beradab, dan disegani bangsa-bangsa lain.

Karena itu, semua pihak termasuk keluarga - dalam hal ini orang tua - harus memiliki kesadaran (awarness) akan pentingnya peran mereka dalam tumbuh kembang anak, sehingga anak-anak menjadi sosok yang berkarakter yang memiliki integritas moral dan intelektual tinggi. Untuk menghasilkan generasi yang berkarakter, orang tua perlu mengimplementasikan pendidikan karakter pada anak-anak mereka sejak dini. Salah satu pendidikan karakter yang dapat ditanamkan kepada anak adalah pendidikan karakter Islami, suatu pendidikan karakter yang berbasis pada ajaran dan nilai-nilai Islam. Terlebih lagi, sebagian besar masyarakat Indonesia menganut agama Islam.

\section{PEMBAHASAN}

Untuk membedah konsep pendidikan karakter Islami, perlu kiranya dikemukakan definisi pendidikan, karakter, dan karakter Islam. Banyak pakar memberikan definisi yang beragam terkait pendidikan. Ki Hajar Dewantara misalnya, memberikan pengertian pendidikan sebagai daya upaya untuk memajukan pertumbuhan nilai moral (kekuatan batin, karakter), dan pikiran (intelect). Lebih lanjut $\mathrm{Ki}$ Hajar Dewantara (dalam Elmubarok, 2007: 2) menjelaskan bahwa antara moral dan pikiran harus saling berhubungan agar dapat memajukan kesempurnaan hidup, yakni 
keselarasan antara kehidupan dan penghidupan.

Sementara M.J Langveld (dalam Abd. Halim Soebahar, 2002: 31) memaparkan bahwa pendidikan adalah sebuah proses memberi pertolongan secara sadar dan sengaja kepada anak (yang belum dewasa) dalam pertumbuhannya menuju kearah dewasa, dalam arti dapat berdiri dan bertanggung jawab susila atas segala tindakan-tindakannya menurut pilihannya sendiri. Selain itu, Langveld mengatakan bahwa pendidikan merupakan wujud proses yang dapat membantu pertumbuhan seluruh unsur kepribadian manusia secara seimbang kearah yang positif.

Berbeda dengan Langveld, Zamroni (dalam Elmubarok, 2007: 3) memberikan definisi pendidikan sebagai suatu proses menanamkan dan mengembangkan pada diri peserta didik pengetahuan tentang hidup, sikap dalam hidup agar kelak ia dapat membedakan barang yang benar dan yang salah, yang baik dan yang buruk, sehingga kehadirannya ditengah-tengah masyarakat akan bermakna dan berfungsi secara optimal.

Tidak jauh berbeda dengan terma pendidikan, beberapa pakar juga telah berusaha memberikan pengertian tentang karakter. Secara etimologis, kata karakter berasal dari bahasa yunani "karasso", yang berarti cetak biru, format dasar, sidik seperti dalam sidik jari. Sebagai contoh misalkan dalam tradisi Yahudi, para tetua melihat alam seperti laut sebagai sebuah karakter, yaitu sebagai sesuatu yang bebas dan tidak dapat dikuasai oleh manusia maupun diintervensi manusia (Doni Koesoema A, 2010: 10). Sementara itu, jika dilacak lebih jauh, karakter berasal dari bahasa latin kharakter,kharassein dan kharax, yang maknanya tools for marking, to engrave dan pointed stake. Kata ini mulai digunakan kembali dalam bahasa prancis caractere pada abad ke-14 dan kemudian masuk dalam bahasa inggris menjadi character. Sementara pengertian karakter sendiri dalam kamus Poerdaminta diartikan sebagai tabiat watak sifat-sifat kejiwaan, akhlak atau budi pekerti yang membedakan seseorang daripada yang lain (Elmubarok, 2007: 102).

Kusrahmadi (2010: 2) memaparkan bahwa karakter adalah sesuatu yang dipahatkan pada hati, sehingga menjadi tanda yang khas. Karakter mengacu pada moralitas dalam kehidupan sehari-hari. Karakter juga bukan merupakan gejala sesaat melainkan tindakan yang konsisten muncul baik secara batiniah dan rohaniah. Karakter adalah serangkaian nilai yang operatif, nilai yang nyata sebagai aktualisasi dalam tindakan. Sementara dari sudut pendidikan, Kusrahmadi Sigit Dwi (2010: 98-99) mendefinisikan karakter sebagai struktur rohani yang terlihat dalam perbuatan dan terbentuk oleh faktor bawaan dan pengaruh lingkungan. Karakter mengacu pada kehidupan etis dan moral seseorang untuk mengasihi Tuhan dan sesama yaitu kebijakan moral untuk berbuat baik. Lebih lanjut Kusrahmadi Sigit Dwi (2010: 101-102) memaparkan bahwa pendidikan karakter merupakan suatu proses pendekatan yang digunakan secara komprehensif. Pendidikan karakter ini hendaknya dilakukan secara kondusif baik di lingkungan sekolah, rumah dan masyarakat, semua partisan dan komunitas yang terlibat di dalamnya.

Koesoema A (2009: 80), menyebut karakter sama dengan kepribadian. Sementara itu, menurut Masnur Muslich (2011: 71), karakter berkaitan dengan kekuatan moral dan berkonotasi positif. Orang yang berkarakter adalah orang yang mempunyai kualitas moral. Berkowitz (dalam Al-Musanna, 2010) mengatakan bahwa karakter merupakan ciri atau tanda yang melekat pada suatu benda atau seseorang. Karakter menjadi penanda identifikasi.

Sementara itu, Thomas Lickona (1992: 13) dalam bukunya yang berjudul educating for character juga menjelaskan pendidikan karakter sebagai berikut:

"Character education is a learning process that enables students and adults in a school community to understand, care about and act on core 
ethical values such as respect, justice, civic virtue and citizenship, and responsibility for self and others. Upon such core values, we form the attitudes and actions that are the ballmark of safe, healthy and informed communities that serve as the foundation of our society."

Selanjutnya, Lickona (1992: 13-19) menguraikan karakter menjadi tiga komponen. Pertama, Moral knowing atau pengetahuan moral terdiri dari: moralawareness (kesadaran atas nilai-nilai moral), knowing moral (mengetahui nilai-nilai moral), perspective taking (mengetahui berbagai perspektive), moral reasoning(mengetahui alasan atas pentingnya moral), decisionmaking (menentukan pilihan untuk mengambil tindakan), dan self knowladge (mengetahui pengetahuan atas diri sendiri). Kedua adalah moral feeling, yang mencakup conscience (hati nurani), self esteem (rasa percaya diri), empathy (merasakan apa yang dirasakan orang lain), loving the good (cinta kebenaran), self control (kontrol diri), dan bumanity (kemanusiaan). Sedangkan yang ketiga adalah Moral action yang mencakup competence (kompetensi), will (kemauan) dan babit (kebiasaan).

Lickona (dalam Bambang Anees dan Adang Hambali, 2008: 99) mendefinisikan pendidikan karakter sebagai pendidikan untuk membentuk kepribadian seseorang melalui pendidikan budi pekerti, yang hasilnya terlihat dalam tindakan nyata seseorang, yaitu tingkah laku yang baik, jujur, bertanggung jawab, menghormati hak orang lain, kerja keras, dan sebagainya. Dalam hal ini, Lickona menekankan pentingnya pendidikan karakter dalam tiga komponen karakter yang baik yaitu moral knowing atau pengetahuan tentang moral, moralfeeling atau perasaan tentang moral dan moral action atau perbuatan moral. Sedangkan Abdullah (2010: 25) menuturkan pendidikan karakter merupakan pendidikan kemanusiaan yang bertujuan menjadikan manusia "baik". Menjadikan manusia "baik" tanpa persyaratan apapun, yaitu tanpa embel-embel syarat agama, sosial, ekonomi, budaya, ras, politik dan hukum.

Sementara itu, berbicara tentang karakter Islami tidak dapat dipisahkan dari terminologi akhlak. Menurut Kully (dalam M. Amin Syukur, 2010: 5), akhlak merupakan sifat jiwa yang sudah terlatih sedemikian kuat, sehingga memudahkan bagi yang melakukan suatu tindakan tanpa pikir dan direnungkan lagi. Ibnu Maskawaih (dalam Syukur, 2010: 5) mendefinisikan akhlak sebagai keadaan jiwa yang mendorong untuk melakukan perbuatanperbuatan tanpa pikir dan dipertimbangkan lebih dahulu. Ibnu Qayyim (dalam Syukur, 2010: 5) menuturkan bahwa akhlak merupakan perangai atau tabi'at yaitu suatu sifat batin dan perangai jiwa yang dimiliki oleh semua manusia. Sedangkan al-Ghazali (dalam Syukur, 2010: 5) mengatakan akhlak merupakan sifat atau bentuk keadaan yang tertanam dalam jiwa, yang dari padanya lahir perbuatan-perbuatan dengan mudah dan gampang tanpa perlu dipikirkan dan dipertimbangkan lagi.

Ali (1998: 347) menyebutkan bahwa akhlak mengandung makna yang ideal, tergantung pada pelaksanaan dan penerapan melalui tingkah laku yang mungkin baik dan mungkin buruk. Yang temasuk dalam pengertian akhlak baik adalah segala tingkah laku, tabiat, watak dan perangai yang sifatnya benar, amanah, sabar, pemaaf, pemurah rendah hati, dan lain-lain. Sementara yang termasuk ke dalam kategori akhlak buruk adalah semua tingkah laku, tabiat, watak, perangai sombong, dendam, dengki, khianat, dan lain-lain yang merupakan sifat buruk.

Karakter Muslim merupakan ciri, watak, kepribadian, dan prilaku seseorang yang berdasarkan konsep-konsep Muslim ideal yang terdapat dalam al-Quran. Dengan kata lain, karakteristik muslim ideal adalah karakteristik Qur'ani yang bersumber dari ajaran al-Qur'an. Dengan karakter Qur'ani tersebut, seorang muslim diharapkan menjadi hamba senantiasa yang menjalankan perintah Allah SWT sesuai dengan petunjukNya (Johansyah, 2011: 91). 
Menurut perspektif Islam, makna penting pendidikan karakter Islami dapat dilihat dari penekanan pendidikan akhlak yang secara teoretis berpedoman pada alQur'an dan secara praktis mengacu kepada kepribadian (personality)Rasulullah SAW. Beliau merupakan role model (teladan) sepanjang zaman. Keteladanannya terilustrasikan secara apik dalam al-Qur'an: "Dan sesungguhnya kamu benar-benar berbudi pekerti yang agung" (Q.S. al-Qalam [68]: 4).

\section{Implementasi Pendidikan Karakter Islami dalam Keluarga}

UU Sistem Pendidikan Nasional No 20 Tahun 2003 Pasal 3 menyebutkan bahwa pendidikan nasional berfungsi mengembangkan kemampuan dan membentuk watak serta peradaban bangsa yang bermartabat dalam rangka mencerdaskan kehidupan bangsa. Pendidikan nasional bertujuan untuk mengembangkan potensi peserta didik agar menjadi manusia yang beriman dan bertakwa kepada Tuhan Yang Maha Esa, berakhlak mulia, sehat, berilmu, cakap, kreatif, mandiri, dan menjadi warga negara yang demokratis serta bertanggung jawab.Berdasarkan fungsi dan tujuan tersebut tampak jelas bahwa pembentukan watak atau karakter menjadi poin utama dalam pendidikan nasional. Pendidikan karakter harus ditanamkan sejak dini kepada anak-anak di setiap jenjang pendidikan, termasuk dalam keluarga.

Jika dibandingkan dengan institusi pendidikan formal, keluarga memiliki peran yang strategis dalam keberhasilan pendidikan karakter dan pendidikan secara umum. Betapa tidak, bila dikalkulasi, peserta didik mengikuti pendidikan di sekolah hanya sekitar 7 (tujuh) jam per hari atau kurang dari $30 \%$. Selebihnya $(70 \%)$, peserta didik berada dalam keluarga dan lingkungan di luar sekolah. Jika dilihat dari aspek kuantitas waktu, pendidikan di sekolah berkontribusi hanya sebesar $30 \%$ terhadap hasil pendidikan peserta didik. Sayangnya, selama ini, pendidikan dalam institusi keluarga belum memberikan kontribusi berarti dalam mendukung pencapaian kompetensi dan pembentukan karakter peserta didik. Kesibukan dan aktivitas kerja orang tua yang relatif tinggi, kurangnya pemahaman orang tua dalam mendidik anak di lingkungan keluarga, pengaruh pergaulan di lingkungan sekitar, dan pengaruh media elektronik tidak sedikit berdampak negatif terhadap pencapaian hasil belajar dan moralitas peserta didik (Akhmad Sudrajat, 2010).

Karena itu, orang tua harus memiliki

kesadaran dan pengetahuan tentang pendidikan karakter. Secara kultural dan teologis, pendidikan karakter bukanlah merupakan entitas yang baru. Disadari atau tidak, pendidikan karakter sejatinya telah ada dan diajarkan secara turun-temurun oleh generasi terdahulu (nenek moyang). Hal ini dapat ditilik dari berbagai tradisi, budaya, karya sastra yang sarat dengan ajaran moral (moral teaching). Ada banyak kearifan lokal (local wisdom) yang dapat diajarkan oleh orang tua kepada anak, semisal larangan berdiri dan duduk di depan mintu, jangan makan dan minum sambil berdiri, jangan duduk di atas bantal, dan sebagainya. Kendati pun generasi terdahulu kerap menggunakan alasan-alasan yang terkesan tidak 'masuk akal' dalam menjelaskan akibat melanggar larangan-larangan tersebut, namun sesungguhnya tujuan mereka adalah baik.

Tidak hanya ada pada budaya dan sastra saja, ajaran agama pun sarat dengan muatan pendidikan karakter. Sebab, agama memang menyediakan seperangkat ajaran moral. Agama menjadi petunjuk (guidance) umat manusia dalam bertindak dan berperilaku. Tak dapat dipungkiri, kehadiran agama di dunia membawa misi moral. Dalam ajaran Islam misalnya disebutkan bahwa Nabi Muhammad SAW sengaja diutus Tuhan ke muka bumi untuk memperbaiki moral umat manusia. Sebagai agama, Islam tentu saja sarat dengan pendidikan karakter dan ajaran moral seperti sopan santun, etos belajar, etos kerja, 
empati, ketekunan, rajin, sabar, pemaaf, pemurah, rendah hati, dan sebagainya.

Bertitik tolak dari eksplanasi tersebut, maka tidak ada alasan bagi orang tua Muslim untuk tidak mengajarkan pendidikan karakter Islami kepada anakanaknya. Orang tua dapat mengajarkan pendidikan karakter Islami dengan cara yang paling sederhana semisal mendongeng atau bercerita tentang kisah-kisah keteladanan Nabi, ashabul kahfi, keluarga Lukmanul Hakim, para walis, para sufi, dan lain-lain. Orang tua juga dapat mengajarkan karakterkarakter yang baik kepada anak-anaknya seperti sopan santun, empati, menghargai orang lain, nasionalisme, etos kerja, bertutur kata yang sopan dan lembut serta berprilaku sesuai dengan norma agama dan masyarakat.

Tidak cukup itu saja, orang tua harus dapat menjadi teladan (uswah) bagi anakanaknya dalam berperilaku dan bertindak. Sebaik apapun materi atau cara orang tua mengajarkan budi pekerti kepada anakanaknya jika tidak dibarengi dengan perbuatan nyata dari orang tua, maka semua itu hanya akan sia-sia. Sebab, pada dasarnya anak-anak cenderung meniru (mengimitasi) sikap, tingkah laku, dan ucapan orang tua atau orang-orang di lingkungannya. Dengan kata lain, pendidikan karakter Islami tidak dapat berjalan secara efektif bilamana hanya diverbalkan. Ia harus diikuti dengan aksi nyata, yakni perbuatan yang positif. Karena itu, konsep learning by doing menjadi sesuatu yang penting dalam keberhasilan pendidikan karakter Islami. Singkatnya, pendidikan keteladanan adalah kata kunci dalam keberhasilan pendidikan karakter Islami. Selain itu, pendidikan karakter Islami dalam keluarga dapat diimplementasikan dengan menggunakan metode pembiasaan (habituasi). Artinya, orang tua harus membiasakan kepada anaknya terhadap sifat, sikap, dan perbuatan yang baik. Misalnya, mengajari anak untuk senantiasa bersikap sopan, bertuntun santun, berbhakti pada orang tua, menghormati yang lebih tua, membuang sampah pada tempatnya, dan sebagainya. Dengan metode pembiasan, karakter-karakter baik akan mudah tertanam dan terinternalisasi pada diri anak.

Apabila anak tidak memiliki lagi orang tua lagi, maka "kewajiban" untuk menanamkan pendidikan keluarga dapat dilakukan oleh keluarga yang lain atau siapapun yang mengasuh anak tersebut. Satu hal yang perlu digarisbawahi adalah bahwa keberhasilan keluarga dalam menanamkan nilai-nilai kebajikan (karakter) pada anak sangat tergantung pada jenis pola asuh yang diterapkan orang tua pada anaknya. Pola asuh dapat didefinisikan sebagai pola interaksi antara anak dengan orang tua yang meliputi pemenuhan kebutuhan fisik (seperti makan, minum dan lain-lain) dan kebutuhan psikologis (seperti rasa aman, nyaman, kasih sayang, dan lain-lain), serta sosialisasi norma-norma yang berlaku di masyarakat agar anak dapat hidup selaras dengan lingkungannya. Dengan kata lain, pola asuh juga meliputi pola interaksi orang tua dengan anak dalam rangka pendidikan karakter anak.

Secara umum, Baumrind mengkategorikan pola asuh menjadi tiga jenis, yaitu: (1) Pola asuh otoriter, (2) Pola asuh demokratis, (3) Pola asuh permisif. Tiga jenis pola asuh Baumrind ini sama seperti jenis pola asuh yang dikemukakan oleh Hurlock juga Hardy \& Heyes. Pola asuh otoriter mempunyai ciri orang tua membuat semua keputusan, anak harus tunduk, patuh, dan tidak boleh bertanya. Pola asuh demokratis mempunyai ciri orang tua mendorong anak untuk membicarakan apa yang ia inginkan. Pola asuh permisif mempunyai ciri orangtua memberikan kebebasan penuh pada anak untuk berbuat. Berikut ini adalah ciri-ciri detail dari ketiga pola asuh. Pola asuh otoriter mempunyai ciri-ciri: (a) Kekuasaan orang tua dominan; (b) Anak tidak diakui sebagai pribadi; (c) Kontrol terhadap tingkah laku anak sangat ketat; (d) Orang tua menghukum anak jika anak tidak patuh. Pola asuh demokratis mempunyai ciri-ciri: (a) Ada kerjasama antara orang tua-anak; (b) Anak diakui sebagai pribadi; (c) Ada bimbingan dan 
pengarahan dari orang tua; (d) Ada kontrol dari orangtua yang tidak kaku. Sedangkan pola asuh permisif mempunyai ciri-ciri: (a) Dominasi pada anak; (b) Sikap longgar atau kebebasan dari orang tua; (c) Tidak ada bimbingan dan pengarahan dari orang tua; (d) Kontrol dan perhatian orangtua sangat kurang (Murtokhid, 2010).

Melalui pola asuh yang dilakukan oleh orang tua, anak belajar tentang banyak hal, termasuk karakter Islami. Tentu saja pola asuh otoriter (yang cenderung menuntut anak untuk patuh terhadap segala keputusan orang tua) dan pola asuh permisif (yang cenderung memberikan kebebasan penuh pada anak untuk berbuat) sangat berbeda dampaknya dengan pola asuh demokratis (yang cenderung mendorong anak untuk terbuka, namun bertanggung jawab dan mandiri) terhadap hasil pendidikan karakter anak. Artinya, jenis pola asuh yang diterapkan oleh orang tua terhadap anaknya menentukan keberhasilan pendidikan karakter anak oleh keluarga. Pola asuh otoriter cenderung membatasi perilaku kasih sayang, sentuhan, dan kelekatan emosi orangtua-anak sehingga antara orang tua dan anak seakan memiliki dinding pembatas yang memisahkan "si otoriter" (orang tua) dengan "si patuh" (anak).

Studi yang dilakukan oleh Fagan (dalam Badingah, 1993) menunjukan bahwa ada keterkaitan antara faktor keluarga dan tingkat kenakalan keluarga, di mana keluarga yang broken home, kurangnya kebersamaan dan interaksi antar keluarga, dan orang tua yang otoriter cenderung menghasilkan remaja yang bermasalah. Pada akhirnya, hal ini akan berpengaruh terhadap kualitas karakter anak. Pola asuh permisif yang cenderung memberi kebebesan terhadap anak untuk berbuat apa saja sangat tidak kondusif bagi pembentukan karakter anak. Bagaimana pun anak tetap memerlukan arahan dari orang tua untuk mengenal mana yang baik dan mana yang salah. Dengan memberi kebebasan yang berlebihan, apalagi terkesan membiarkan, maka akan membuat anak bingung dan berpotensi salah arah.
Pola asuh demokratis tentu saja sangat compatible dengan pendidikan karakter anak. Hal ini dapat dilihat dari hasil penelitian yang dilakukan oleh Baumrind yang memaparkan bahwa orang tua yang demokratis lebih mendukung perkembangan anak, terutama dalam kemandirian dan tanggung jawab. Sementara, orang tua yang otoriter merugikan. Hal ini lantaran anak tidak mandiri, kurang tanggung jawab serta agresif. Sementara orang tua yang permisif mengakibatkan anak kurang mampu dalam menyesuaikan diri di luar rumah (Murtokhid, 2010).

Dalam sebuah studi, Arkoff menuturkan bahwa anak yang dididik dengan cara demokratis umumnya cenderung mengungkapkan agresivitasnya dalam tindakan-tindakan yang konstruktif atau dalam bentuk kebencian yang sifatnya sementara saja. Di sisi lain, anak yang dididik secara otoriter memiliki kecenderungan untuk mengungkapkan agresivitasnya dalam bentuk tindakan-tindakan merugikan. Sementara itu, anak yang dididik secara permisif cenderung mengembangkan tingkah laku agresif secara terbuka atau terang-terangan (Jarwo Murtokhid, 2010).

Hasil penelitian Rohner (dalam Megawangi, 2003) menyebutkan bahwa pengalaman masa kecil seseorang sangat mempengaruhi perkembangan kepribadiannya (karakter atau kecerdasan emosinya). Penelitian tersebut - yang menggunakan teori PAR (Parental AcceptanceRejection Theory)- menunjukkan bahwa pola asuh orang tua, baik yang menerima (acceptance) atau yang menolak (rejection) anaknya, akan mempengaruhi perkembangan emosi, perilaku, sosialkognitif, dan kesehatan fungsi psikologisnya ketika dewasa kelak.

Dari eksplanasi di atas jelas bahwa jenis pola asuh yang diterapkan orang tua kepada anaknya sangat menentukan keberhasilan pendidikan karakter anak. Kesalahan dalam pengasuhan anak akan berakibat pada kegagalan dalam 
pembentukan karakter yang baik. Menurut Megawangi (2003), ada beberapa kesalahan orang tua dalam mendidik anak yang dapat mempengaruhi perkembangan kecerdasan emosi anak sehingga berakibat pada pembentukan karakternya, yaitu:

Pertama, Kurang menunjukkan ekspresi kasih sayang baik secara verbal maupun fisik.

Kedua, Kurang meluangkan waktu yang cukup untuk anaknya.

Ketiga, Bersikap kasar secara verbal, misainya menyindir, mengecilkan anak, dan berkata-kata kasar.

Keempat, Bersikap kasar secara fisik, misalnya memukul, mencubit, dan memberikan hukuman badan lainnya.

Kelima, Terlalu memaksa anak untuk menguasai kemampuan kognitif secara dini.

Keenam, Tidak menanamkan good character kepada anak.

Implikasi negatif yang ditimbulkan dari salah asuh sebagaimana dikemukakan di atas, menurut Megawangi akan menghasilkan anak-anak yang mempunyai kepribadian bermasalah atau mempunyai kecerdasan emosi rendah, yaitu:

Pertama, Anak menjadi acuh tak acuh, tidak butuh orang lain, dan tidak dapat menerima persahabatan. Karena sejak kecil mengalami kemarahan, rasa tidak percaya, dan gangguan emosi negatif lainnya. Ketika dewasa ia akan menolak dukungan, simpati, cinta dan respons positif lainnya dari orang di sekitarnya. Ia kelihatan sangat mandiri, tetapi tidak hangat dan tidak disenangi oleh orang lain.

Kedua, Secara emosiol anak tidak responsif. Anak yang ditolak cenderung akan tidak mampu memberikan cinta kepada orang lain.

Ketiga, Anak berperilaku agresif, yaitu selalu ingin menyakiti orang baik secara verbal maupun fisik.

Keempat, Anak menjadi minder, merasa diri tidak berharga dan berguna.

$$
\text { Kelima, Anak senantiasa }
$$

berpandangan negatif pada lingkungan sekitarnya, seperti rasa tidak aman, khawatir, minder, curiga dengan orang lain, dan merasa orang lain sedang mengkritiknya.

Keenam, Anak mengalami ketidakstabilan emosi, yaitu tidak toleran atau tidak tahan terhadap stress, mudah tersinggung, mudah marah, dan sifat yang tidak dapat dipreaiksi oleh orang lain.

Ketujuh, Berpengaruh terhadap keseimbangan antara perkembangan emosional dan intelektual anak. Dampak negatif lainnya dapat berupa mogok belajar, dan bahkan dapat memicu kenakalan remaja, tawuran, dan lainnya.

Kedelapan, Orang tua yang tidak memberikan rasa aman dan terlalu menekan anak, akan membuat anak merasa tidak dekat, dan tidak menjadikan orang tuannya sebagai "role model" anak akan lebih percaya kepada peer group-nya, sehingga mudah terpengaruh dengan pergaulan negatif (Ratna Megawangi, 2003).

Idealnya, setiap keluarga (orang tua) harus mampu mengimplementasikan pola asuh yang demokratis kepada anak-anaknya. Dengan demikian, keberhasilan pendidikan karakter Islami dalam institusi keluarga akan terwujud. Kegagalan keluarga Muslim dalam melakukan pendidikan karakter Islami pada anak-anaknya, akan mempersulit institusiinstitusi lain di luar keluarga (termasuk sekolah) dalam upaya memperbaikinya. Kegagalan keluarga dalam membentuk karakter anak akan berakibat pada tumbuhnya masyarakat yang tidak berkarakter. Karenanya, setiap keluarga, tak terkecuali keluarga Muslim, harus memiliki kesadaran bahwa karakter bangsa sangat tergantung pada pendidikan karakter anakanak mereka dalam keluarga. Setiap keluarga harus memiliki kesadaran bahwa karakter bangsa sangat bergantung pada pendidikan karakter anak di rumah.

\section{Signifikansi Pendidikan Karakter Islami bagi Kemajuan Bangsa}

Dalam UU No. 20 Tahun 2003 tentang sistem Pendidikan Nasional (2007) Pada Pasal 3, disebutkan bahwa pendidikan 
Nasional berfungsi mengembangkan kemampuan dan membentuk karakter serta peradaban bangsa yang bermartabat dalam rangka mencerdaskan kehidupan bangsa. Pendidikan Nasional bertujuan untuk mengembangkan potensi serta didik agar menjadi manusia yang beriman dan bertakwa kepada Tuhan Yang Maha Esa, berakhlak mulia, berilmu, sehat, cakap, kreatif, mandiri, dan menjadi warga negara yang demokratis serta bertanggung jawab.

Namun realitasnya, tujuan yang diharapkan dan diinginkan oleh Undangundang tersebut belum sepenuhnya terwujud. Hal ini ditandai dengan banyaknya manusia-manusia yang cerdas secara intelektual, namun culas secara moral. Degradasi moral inilah salah satu faktor yang menjadikan bangsa Indonesia terpuruk. Kondisi bangsa Indonesia saat ini memang cukup memprihatinkan. Di negeri yang dahulu terkenal dengan keramahannya ini kerap terjadi tindak kekerasan dan konflik berbasis Suku, Agama, Ras, dan Antargolongan (SARA). Korupsi menggurita di mana-mana di hampir setiap instansi birokrasi dan kian menjadi-jadi. Jurang kemiskinan kian dalam dan menganga. Supremasi hukum di negeri ini seperti tidak ada. Alhasil, bangsa ini sungguh-sungguh terjebak dalam kubangan krisis moral yang berkepanjangan. Kondisi bangsa ini tidak ubahnya seperti orang yang sakit.

Pendidikan moral yang diajarkan di institusi-institusi pendidikan di Indonesia ternyata belum cukup mampu berkontribusi dalam pembentukan karakter anak bangsa. Alih-alih dapat membentuk karakter, pendidikan moral yang diajarkan di sekolahsekolah melalui pelajaran agama \& PKn selama ini justru terjebak pada pragmatisme dan dogmatisme. Pelajaran-pelajaran tersebut (dan mata pelajaran lainnya) selama ini lebih banyak hanya menyentuh aspek pengetahuan saja (kognitif) dan belum banyak menyentuh aspek afektif dan psikomotorik (prilaku). Proses pembelajaran yang dilakukan oleh peserta didik pada umumnya hafalan saja, sehingga tidak mampu mengubah prilaku seseorang menjadi lebih baik.

Dalam konteks inilah, kehadiran pendidikan karakter Islami menjadi begitu signifikan dan dinantikan. Institusi sekolah sejatinya sangat diharapkan untuk dapat mengajarkan dan menanamkan nilai-nilai pendidikan karakter Islami kepada anakanak. Namun realitasnya, institusi sekolah tidak selalu dapat diharapkan. Pendidikan karakter (Islami) yang diajarkan di sekolah selama ini dirasa tidak cukup optimal. Oleh karena itu, institusi keluarga diharapkan mampu menutupi kekurangan pendidikan karakter di institusi sekolah. Dalam konteks inilah, menurut hemat penulis, institusi keluarga memiliki peran penting dan strategis dalam menanamkan pendidikan karakter Islami kepada anak-anak yang notabene kelak menjadi generasi penerus bangsa.

Penulis meyakini bahwa pendidikan karakter Islami sangat bermanfaat bagi kemajuan bangsa Indonesia. Meskipun penulis akui hal itu bukanlah satu-satunya cara. Banyak sosiolog yang mengatakan bahwa keluarga memiliki peran penting dalam menentukan kemajuan suatu bangsa, sehingga mereka berteori bahwa keluarga adalah unit yang penting sekali dalam masyarakat. Jika keluarga-keluarga yang merupakan fondasi masyarakat lemah, maka masyarakat pun akan lemah. Oleh karena itu, tidak sedikit sosiolog meyakini bahwa berbagai masalah masyarakat merupakan akibat dari lemahnya institusi keluarga.

Di era (pos)modern yang kosmopolit ini, semua negara dihadapkan pada tantangan-tantangan global yang menuntutnya berkompetisi dan berinteraksi satu sama lain. Banyak kalangan yang menyebut era ini sebagai era globalisasi. Di era globalisasi yang ditandai dengan perkembangan alat transportasi dan media teknologi informasi yang kian canggih ini, jarak teritorial negara bukan menjadi halangan lagi untuk saling berinteraksi. Perjumpaan dan interaksi satu 
individu/komunitas

dengan

individu/komunitas lain atau satu negara dengan negara lain yang beragam latar belakang (budaya, agama, sosial, ekonomi, pendidikan, etnis, dan lain-lain) dengan segenap nilai yang dibawanya tentunya menjadi realitas yang tak terelakkan. Beragam nilai dan budaya tersebut membawa konsekuensi-konsekuensi, baik konsekuensi positif maupun konsekuensi negatif. Dengan ungkapan lain, globalisasi tidak ubahnya seperti dua sisi dalam satu mata uang, bersisi positif dan negatif. Tentu saja yang perlu diwaspadai adalah konsekuensi atau dampak negatif dari globalisasi, yakni merosot atau melunturnya nilai-nilai moralitas akibat pengaruh budaya lain yang negatif.

Di sinilah harus disadari bahwa tidak semua budaya dan tradisi dari luar sesuai dan baik bagi masyarakat Indonesia dan sesuai dengan nilai-nilai Islam. Oleh karena itu, melalui pendidikan karakter Islami, masyarakat Muslim Indonesia dituntut dapat memilih dan memilah budaya yang sesuai dengan ajaran Islam dan jati diri bangsa. Melalui pendidikan karakter Islami pula, Muslim Indonesia diharapkan memiliki kualitas dan integritas moral yang kokoh, sehingga mampu membawa bangsa Indonesia menjadi bangsa yang bermartabat, maju, mandiri, dan madani. Karena itulah, sekali lagi, keluarga sebagai institusi pendidikan pertama memainkan peran penting dan sentral dalam melahirkan generasi bangsa yang berkarakter guna merealisasikan cita-cita besar tersebut.

Tingginya karakter masyarakat sebuah bangsa akan membawanya kepada sebuah peradaban, kemajuan, dan kedamaian. Jika karakter/akhlak masyarakatnya rendah, maka suatu bangsa tidak mampu mengembangkan diri ke arah kemajuan dan peradaban yang baik dan disegani. Bahkan rendahnya akhlak dan rusaknya karakter individu dalam masyarakat berpotensi menyebabkan musnahnya suatu bangsa. Al-Quran banyak menceritakan bahwa Allah SWT menghancurkan suatu bangsa karena kemerosotan moral. Salah satunya adalah cerita kaum Nabi Nuh yang ditenggelamkan. Terkait makna pentingnya karakter/akhlak dalam suatu bangsa, seorang penyair Arab, Syauqy, pernah mengatakan: "Sesungguhnya kejayaan suatu bangsa terletak pada akhlaknya selagi mereka berakhlak/berbudi perangai utama, jika pada mereka telah hilang akhlaknya, maka jatuhlah bangsa tersebut" (Johansyah, 2011: 95).

Oleh karena itu, kehadiran pendidikan karakter Islami sangat signifikan dan urgen untuk diimplementasikan dalam keluarga Muslim Indonesia. Tanpa bermaksud menegasikan peran dan kontribusi masyarakat non-Muslim, sebagai mayoritas, maju-mundurnya bangsa Indonesia tentu saja sangat ditentukan umat Muslim. Jika seluruh keluarga Muslim Indonesia mampu menerapkan pendidikan karakter Islami dengan baik, maka sejatinya umat Muslim telah berandil besar dalam membangun karakter dan kemajuan bangsa.

\section{KESIMPULAN}

Berdasarkan uraian di atas dapat disimpulkan bahwa pendidikan karakter Islami memiliki makna penting dan kontribusi dalam pembangunan karakter bangsa. Era globalisasi yang tengah dihadapi bangsa Indonesia tentu saja membawa dampak positif dan juga dampak negatif. Salah satu dampak negatif dari globalisasi adalah melunturnya nilai-nilai moralitas akibat pengaruh budaya lain yang negatif. Melalui pendidikan karakter Islami, masyarakat Muslim Indonesia dituntut dapat memilih dan memilah budaya yang sesuai dengan ajaran Islam dan jati diri bangsa. Melalui pendidikan karakter Islami pula, Muslim Indonesia diharapkan memiliki kualitas dan integritas moral yang kokoh, sehingga mampu membawa bangsa Indonesia menjadi bangsa yang maju, disegani, dan bermartabat.

Dalam konteks inilah, keluarga sebagai institusi pendidikan pertama 
memainkan peran penting dan sentral dalam melahirkan generasi bangsa yang berkarakter. Implementasi karakter pendidikan Islami di level keluarga dapat dilakukan dengan mengajarkan anak pada tentang pentingnya berprilaku Islami seperti memiliki etos kerja yang tinggi, jujur, tekun, rajin, sabar, pemaaf, pemurah, rendah hati, dan sebagainya. Dalam penanaman pendidikan karakter Islami, orang tua harus mampu menjadi teladan bagi anak-anaknya dalam bersikap dan bertindak. Sebab, pada dasarnya anak-anak cenderung meniru (mengimitasi) sikap, tingkah laku, dan ucapan orang tua atau orang-orang di lingkungannya. Karena itu, konsep learning by doing menjadi sesuatu yang penting dalam keberhasilan pendidikan karakter Islami. Di samping itu, pendidikan karakter Islami juga akan lebih efektif jika menggunakan metode pembiasaan. Orang tua harus membiasakan kepada anaknya terhadap sifat, sikap, dan perbuatan yang baik. Misalnya, mengajari anak untuk senantiasa bersikap sopan, bertuntun santun, berbhakti pada orang tua, menghormati yang lebih tua, membuang sampah pada tempatnya, dan sebagainya. Dengan metode pembiasan, karakterkarakter baik akan mudah tertanam dan terinternalisasi pada diri anak. Last but not least, tanpa adanya keteladanan dan pembiasaan, penanaman pendidikan karakter Islami tidak akan berhasil dengan baik.

\section{DAFTAR PUSTAKA}

Al-Musanna. (2010). Revitalisasi Kurikulum Muatan Lokal untuk Pendidikan Karakter Melalui Evaluasi Responsif. Jurnal Pendidikan dan Kebudayaan, Volume 16 Edisi khusus III, Oktober, Balitbang Kementerian Pendidikan Nasional.

Anees, Bambang dan Adang Hambali. (2008). Pendidikan Karakter Berbasil Al-Qur'an. Bandung: Simbiosa Rekatama Media.
Badingah, Siti. (1993). Agresivitas Remaja Kaitannya dengan Pola Asuh, Tingkah Laku Agresif Orang Tua dan Kegemaran Menonoton Film Keras. Depok: Program Studi Psikologi Pascasarjana Universitas Indonesia.

Elmubarok, Zaim. (2007). Menyambung yang Terputus dan Menyatukan yang Tercerai. Bandung: ALFABETA.

Johansyah. (2011). Pendidikan Karakter dalam Islam: Kajian dari Aspek Metodologis. Jurnal Ilmiah Islam Futura, Volume XI, No. 1, Agustus, hlm. 85-103.

Koesoema A., Doni. (2010). Pendidikan Karakter Strategi Mendidik Anak di Zaman Keblinger. Jakarta: Grasindo.

Kusrahmadi, Sigit Dwi. (2010). Pentingnya Pendidikan Karakter Yang Baik Bagi

Anak Sekolah Dasar, Seminar Nasional dalam Rangka Dies Natalis UNY ke-46 bertema: Membangun Pendidikan Karakter Perspektif Karakter Dan Kebangsaan, kerjasama Fakultas Ilmu Sosial dan Ekonomi UNY dengan SKH Kedaulatan Rakyat, Yogyakarta, 12 Mei 2010.

Lickona, Thomas. (1992). Educating for Character How Our School Can Teach Respect and Responsibility. New York: Bantam Book.

Megawangi, Ratna. (2003). Pendidikan Karakter untuk. Membangun Masyarakat Madani. Jakarta: IPPK Indonesia Heritage Foundation.

Murtokhid, Jarwo. (2010). Membangun Karakter, (http:/ / cahayaswarahati.blog spot.com/ 2010/01/membangunkarakter.html). Diunduh pada 2 Februari 2017.

Muslich, Masnur. (2011). "Pendidikan Karakter: Menjawab Tantangan Krisis Multidimensional", Jakarta: Bumi Aksara.

Soebahar, Abd. Halim. (2002). "Wawasan Baru Pendidikan Islam", Jakarta: Kalam Mulia. 
Sudrajat, Akhmad. (2010). Tentang

Pendidikan Karakter,

(https://akhmad

sudrajat.wordpress.com/2010/08/2

$0 /$ pendidikan-karakter-di-smp/).

Diunduh pada 9 Januari 2017.

Syukur, M. Amin. (2010). Studi Akblak. Semarang: Wali Songo Press.

UU Sisdiknas (UU RI No. 20 Th. 2003).

(2007). Jakarta: Sinar Grafika. 